\title{
Article \\ Erratum: Alhasnawi et al. A New Robust Control Strategy for Parallel Operated Inverters in Green Energy Applications. Energies 2020, 13, 3480
}

\author{
Bilal Naji Alhasnawi ${ }^{1, *(\mathbb{D})}$, Basil H. Jasim ${ }^{1}(\mathbb{D})$, Walid Issa ${ }^{2}\left(\mathbb{D}\right.$, Amjad Anvari-Moghaddam $^{3}(\mathbb{D})$ \\ and Frede Blaabjerg ${ }^{3}$ (D) \\ 1 Electrical Engineering Department, University of Basrah, Basrah 61001, Iraq; hanbas632@gmail.com \\ 2 Electrical Engineering Department, Sheffield Hallam University, Pond Street, Sheffield S1 1WB, UK; \\ walid.issa@shu.ac.uk \\ 3 Department of Energy Technology, Aalborg University, 9220 Aalborg, Denmark; aam@et.aau.dk (A.A.-M.); \\ fbl@et.aau.dk (F.B.) \\ * Correspondence: bilalnaji11@yahoo.com; Tel.: +964-780909854
}

check for updates

Citation: Alhasnawi, B.N.; Jasim, B.H.; Issa, W.; Anvari-Moghaddam, A.; Blaabjerg, F. Erratum: Alhasnawi et al. A New Robust Control Strategy for Parallel Operated Inverters in Green Energy Applications. Energies 2020, 13, 3480. Energies 2022, 15, 40. https://doi.org/10.3390/en 15010040

Received: 26 October 2020 Accepted: 27 December 2020 Published: 22 December 2021

Publisher's Note: MDPI stays neutral with regard to jurisdictional claims in published maps and institutional affiliations.

Copyright: (C) 2021 by the authors Licensee MDPI, Basel, Switzerland. This article is an open access article distributed under the terms and conditions of the Creative Commons Attribution (CC BY) license (https:// creativecommons.org/licenses/by/ $4.0 /)$.
The authors wish to make the following corrections to this paper [1]. A modification to the list of authors, contribution section as well as references as follows:

\section{List of authors:}

Bilal Naji Alhasnawi ${ }^{1, *}$, Basil H. Jasim ${ }^{1}$, Walid Issa ${ }^{2}$, Amjad Anvari-Moghaddam ${ }^{3}$ and Frede Blaabjerg ${ }^{3}$

1 Electrical Engineering Department, University of Basrah, Basrah 61001, Iraq; hanbas632@gmail.com

2 Electrical Engineering Department, Sheffield Hallam University, Pond Street, Sheffield S1 1WB, UK; walid.issa@shu.ac.uk

3 Department of Energy Technology, Aalborg University, 9220 Aalborg, Denmark; aam@et.aau.dk (A.A.-M.); fbl@et.aau.dk (F.B.)

* Correspondence: bilalnaji11@yahoo.com; Tel.: +964-780909854

Author Contributions: B.N.A.: writing—original draft, software, methodology, and validation; B.H.J.: formal analysis, investigation, resources, writing — review and editing; W.I.: methodology, resources; A.A.-M.: supervision, funding, writing - review and editing, F.B.: supervision, writing-review and editing. All authors have read and agreed to the published version of the manuscript.

\section{References List:}

These two references at the same place in Section 5 in page 14 after the first sentence. This paper utilized the hybrid microgrid model to evaluate the system stability during abrupt changes in the load and with significant line impedance mismatch [38] and [53].

Two newly added references:

38. Issa, W.; Sharkh, S.; Abusara, M. Hybrid Generators-based AC Microgrid Performance Assessment in Island Mode. IET Power Electr. 2019, 12, 1973-1980. http:/ / doi.org/10 .1049/iet-pel.2018.5295.

53. Issa, W.R.M. Improved Control Strategies for Droop-Controlled Inverter-Based Microgrid, Doctor of Philosophy in Renewable Energy; University of Exeter: Exeter, UK, 2015. 
We apologize for any inconvenience caused to the readers by these changes. The change does not affect the scientific results. The manuscript will be updated, and the original will remain online on the article webpage.

\section{Reference}

1. Alhasnawi, B.N.; Jasim, B.H.; Issa, W.; Anvari-Moghaddam, A.; Blaabjerg, F. A New Robust Control Strategy for Parallel Operated Inverters in Green Energy Applications. Energies 2020, 13, 3480. [CrossRef] 